\title{
WATER PRODUCTIVITY FOR BORO RICE PRODUCTION: STUDY ON FLOODPLAIN BEELS IN RAJSHAHI, BANGLADESH
}

\author{
Md. Istiaque Hossain ${ }^{* 1,2}$, Chamhuri Siwar ${ }^{1}$, Mazlin Bin Mokhtar ${ }^{1}$, Madan \\ Mohan Dey ${ }^{3}$, Abd. Hamid Jaafar ${ }^{4}$ and Md. Mahmudul Alam ${ }^{1}$ \\ ${ }^{1}$ Department of Fisheries, University of Rajshahi, Rajshahi-6205, Bangladesh \\ ${ }^{2}$ Universiti Kebangsaan Malaysia (UKM) 43600 UKM BANGI, Selangor, \\ Malaysia \\ ${ }^{3}$ Aquaculture Economics and Marketing Aquaculture/Fisheries Center University \\ of Arkansas Pine Bluff, USA \\ ${ }^{4}$ Graduate Program Coordinator Faculty of Business, Universiti Kebangsaan \\ Malaysia
}

\section{Citation Reference:}

Hossain, M.I., Siwar, C., Mokthar, M., Dey, M.M., Jaafar, A.H., and Alam, M.M. 2013. Water Productivity for Boro Rice Crop Production: Study on Floodplain Beels in Rajshahi, Bangladesh. Journal of Bio-Science, 21: 123-136. Available http://www.banglajol.info/index.php/JBS/article/view/22526

This is a pre-publication copy.

The published article is copyrighted by the publisher of the journal.

\footnotetext{
* Corresponding author: E-mail: bitanrubd@yahoo.com , bitan@ru.ac.bd
} 


\title{
WATER PRODUCTIVITY FOR BORO RICE PRODUCTION: STUDY ON FLOODPLAIN BEELS IN RAJSHAHI, BANGLADESH
}

\author{
Md. Istiaque Hossain ${ }^{* 1,2}$, Chamhuri Siwar', Mazlin Bin Mokhtar'1, Madan Mohan Dey, \\ Abd. Hamid Jaafar ${ }^{4}$ and Md. Mahmudul Alam ${ }^{1}$ \\ ${ }^{1}$ Department of Fisheries, University of Rajshahi, Rajshahi-6205, Bangladesh \\ 2Universiti Kebangsaan Malaysia (UKM) 43600 UKM BANGI, Selangor, Malaysia \\ ${ }^{3}$ Aquaculture Economics and Marketing Aquaculture/Fisheries Center University of Arkansas Pine Bluff, USA \\ ${ }^{4}$ Graduate Program Coordinator Faculty of Business, Universiti Kebangsaan Malaysia
}

\begin{abstract}
Context: Water productivity is considered as an important indicator of Agriculture productivity because of the scarcity of freshwater. More yield or output against same or less amount of water has become the global interest.

Objectives: This study measures the productivity of water on the floodplain land in terms of Boro rice cultivation for two floodplain beels in Rajshahi Bangladesh.

Materials \& Methods: For this study, the production and market price data were collected by direct observation based on 30 samples in the year 2006-07.

Results: This study found gross water productivity of rice yield as $0.47 \mathrm{~kg} \mathrm{~m}^{-3}$ in beel Mail and $0.43 \mathrm{~kg}$ $\mathrm{m}^{-3}$ in beel Chandpur. In monetary value, water productivity per cubic meter irrigation water were TK 5.65, TK 3.42 and TK 2.64 based on gross return, net return considering cash costs and net return considering full costs in beel Mail. In beel Chandpur these values were TK $5.19 \mathrm{~m}^{-3}$, TK $2.87 \mathrm{~m}^{-3}$ and TK $2.14 \mathrm{~m}^{-3}$, respectively. The usage of average irrigated water in the boro rice farms were estimated $10730.05 \mathrm{~m}^{-3}$ and $11236 \mathrm{~m}^{-3}$ with an average production of yield $4992.95 \mathrm{~kg}$ and $4783.20 \mathrm{~kg}$ in beel Mail and beel Chandpur. Statistical result shows that keeping irrigation water constant, a $1 \%$ increase of boro rice yield will increase water productivity at $0.916 \%$ in beel Mail and $0.972 \%$ in beel Chandpur. The water productivity in beel Mail was $4.65 \%$ higher than beel Chandpur due to the intervention of community based fish culture management.

Conclusion: The findings of this study will help to govern and improve production by proper utilizing floodplain lands.
\end{abstract}

Keywords: water productivity; Boro production; Floodplain; Bangladesh; beel.

\section{Introduction}

Water productivity (WP) generally refers to productivity against unit amount of water used. So it implies to efficient water use that can be increased by either producing more output per unit of water used or by reducing water losses or by the combination of both. Therefore, the concept of WP in Agricultural production systems has focused on 'producing more food with the same water resources' or 'producing the same amount of food with less water resources'.

Freshwater resources are facing increased competition among a multitude of users (Pimentel et al. 2004, Rijsberman 2006). In this water scarcity conditions, the limited available water should be used more efficiently (Bessembinder et al. 2005). There are two key challenges in front of Agriculture- food production needs to enhance for rapidly growing world population and this demand needs to be fulfilled under decreasing water resources. FAO's (2003) report on World Agriculture: towards 2015/30 projects mentioned that global food production will need to increase by $60 \%$ to close nutrition gaps, cope with the population growth and accommodate changes in diets over the next three decades. Water withdrawals for Agriculture

\footnotetext{
* Corresponding author: E-mail: bitanrubd@yahoo.com , bitan@ru.ac.bd
} 
are expected to increase by some $14 \%$ in that period, representing an annual growth rate of $0.6 \%$, down from $1.9 \%$ in the period $1963-1999$. Much of the increase will take place on arable irrigated land, forecast to expand globally from some 2 million sq. $\mathrm{km}$ to 2.42 million sq. $\mathrm{km}$. In a group of 93 developing countries water use efficiency in irrigation, i.e. the ratio between water consumption by crops and the total amount of water withdrawn, is expected to grow from an average $38 \%$ to $42 \%$.

To meet up the food shortage, it is needed to produce more food from limited water by increasing WP(Dugan et al. 2006, Guerra et al. 1998). Molden and Saktivadivel (1999) define WP as the value or weight obtained per unit of water used or consumed. Sharma (2006) also defines productivity of water as the benefits derived from use of water and is most often given in terms of mass of produce, or its monetary value, per unit of water. According to him, WP is dependent on several factors, including crop genetic material, water management practices and the economic and policy incentives to produce. Integrated Water Management Institute (IWMI) researchers have been of the view that this definition is scale dependent. For a farmer, it means getting more crops per drop of irrigation water. But at a regional, basin or a country level WP means getting more value per unit of water resources used. Increasing WP is then the business of several actors working in harmony at plant, field, irrigation-system and river basin levels (Sharma 2006). Various stakeholder groups define WP differently according to water use. Molden (1997) defines WP as 'crop production' per unit 'amount of water used'. It can be further defined in several ways according to the purpose, scale and field of analysis (Bastiaanssen et al. 2003, Molden et al. 2001).

Some researchers have focused on measuring crop WP values, calculated as the ratio of yield over evapotranspiration, at crop or field level for different crops. Zawrat and Bastiaanssen (2004) reviewed 84 literatureswhich are not older than 25 years and found profound variations of crop WP for unit amount of water depletion. The range of crops WPis very wide (wheat, $0.6-1.7 \mathrm{~kg} \mathrm{~m}^{-3}$; rice, $0.6-1.6 \mathrm{~kg} \mathrm{~m}^{-3}$; cotton seed, $_{\text {, }}$ $0.41-0.95 \mathrm{~kg} \mathrm{~m}^{-3}$; cottonlint, $0.14-0.33 \mathrm{~kg} \mathrm{~m}^{-3}$ and maize, $1.1-2.7 \mathrm{~kg} \mathrm{~m}^{-3}$ ) and thus offers tremendous opportunities for maintaining or increasing agricultural production by $20-40 \%$ less water resources.

Different economic WP was also found by authors in various crops.Molden et al. (1998) and Molden et al. (2001) found economic WP for wheat crop in South East Asia ranging from $\$ 0.07$ to $\$ 0.17$ per $\mathrm{m}^{3}$ irrigation water. Whereas Merrett (1997) found, economic WP in Jordan ranged from $\$ 0.03 \mathrm{~m}^{-3}$ for wheat to $\$ 0.3 \mathrm{~m}^{-3}$ for potato. Thus the WP values differ by crops, environment, socioeconomic condition and farming pattern.

Wetlands are important ecosystem that supports a wide range of biodiversity and provides numerous benefits. These wetlands, especially the flood prone ecosystems have the potential to be utilized for WPenhancing measures. Floodplain is a low lying flat land which is adjacent to a stream or river that experiences occasional or periodic flooding (Powell , 2009). It is a dry area susceptible to being inundated by water from any natural resource. Some places, like Bangladesh, farmlands that become flooded (over 1 meter depth) during wet season are known as floodplain. Beel is a very common form of floodplain area in the Ganga-Brahmaputra floodplains of the states of West Bengal, and Assam in India and in Bangladesh. It is formed by inundation of low lying lands during flooding, where some water gets trapped even after flood waters recede back from the floodplains. It also may be caused by rain water during monsoon season. There are two types of beels viz., the seasonal beels which dry-up annually and the perennial beels which retain water round the year. Beels may be formed from great river when the mainstream of the river changes the direction leaving a remnant. Again this can be formed as a result of silt deposition in the river bed which makes the river to flow with two parallel streams leaving a land in between. The land between a pair of parallel rivers then forms a ditch or depression which is converted to beel during flooding (Alam \& Hossain 2007).

Bangladesh has one of the largest and richest floodplain lands in the world (Rahman, 1989, Tsai et al. 1993). In Bangladesh $80 \%$ of the total land area are said to be floodplain. $60 \%$ of the country is less than six meters above sea level (Hofer \& Messerli 1997). During the rainy season (July -September) huge quantity of water, enter the country on its way to the Bay of Bengal. At the same time about $90 \%$ of annual rainfall also occurs. 
For this reason, two thirds of Bangladesh is vulnerable to flooding and almost every year a third to a quarter of the country goes under water (Nishat, 1990). More than half of rice land in Bangladesh (10.2 million hectares) is flooded to the depth of more than $50 \mathrm{~cm}$ during the rainy season (IFAD \&World Fish Center 2002). In 1986, the Master Plan Organization (MPO) for National Planning estimated the Net Cultivable Area (NCA) of Bangladesh to be 9,562,402 hectares, out of which 6,300,723 hectares were said to be floodplains susceptible to annual submersion to different depths. Whereas, Welcomme (1979) estimated 9,300,000 hectares of floodplain area in Bangladesh, which includes 2,834,000 hectares of paddy fields.

Therefore, proper utilization of water is very important for sustainable Agriculture and rural economic development. At the same time, new policies and initiatives are required for the adaptation of WP enhancing measures (FAO 2001). With this view in mind, assessment of WP of seasonal floodplain water body is very potential to produce more food from the same water resources. Therefore this study is an attempt to fill up the knowledge gap through measuring the productivity of water of the floodplain land in terms of rice production based on two beels in Bangladesh.

\section{Methodology}

\section{Study Area}

The study was conducted on two beels which are situated in Mohanpurupazila of Bangladesh. Mohanpur is a - upazila under Rajshahi district. It is situated between $24^{\circ} 28^{\prime}$ and $24^{\circ} 38^{\prime}$ North latitude and between $88^{\circ} 34^{\prime}$ and $88^{\circ} 43^{\prime}$ east latitude having an area of $162.65 \mathrm{sq} \mathrm{km}$ (figure 1).

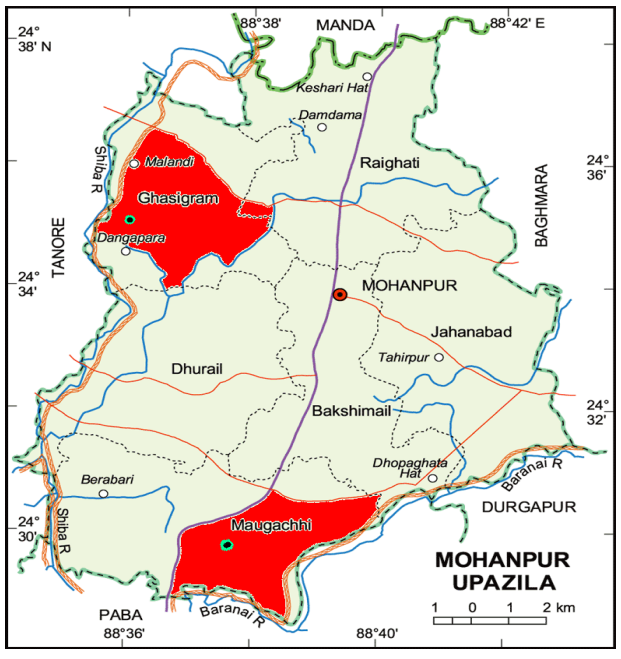

Fig. 1. Study areas in Mohanpur upazila

Source: http://banglapedia.search.com.bd/HT/N_0049.htm

The beel Mail is an open beel that is shallow depressions where land is converted to Agriculture while permanent water is limited to deeper areas during dry season (Thompson et al. 1999) connected nearby a local Shiba River, which further connected to Padma river basin. This floodplain beel is mainly privately owned lands with total 100 hectare area of which 15 hectare government Khas lands having water availability for 5-6 month. After flood draw down the beel completely drains out the water during dry season leaving fertile land suitable for rice cultivation. Melandi, Goalpara, Dangapara and Moheskundi villagers are the main beneficiaries of this beel. 
The beel Chandpur is also mostly privately owned lands with total 202.43 hectares of land of which 9.15 hectares of land are Government's khas land. The depth of water is 1.5 to 3.5 meters having 5-6 months of water during the wet season. This beel is connected with Barnoi River, which further connected to Padma basin. Farmers mainly grow Boro rice at the dry season and some are growing Amon crops in the low level area during the wet season. There are 5 villages surrounding the beel area namely Batupara, Horiphala, Chandpur, Chuniapara and Nondonhut.

\section{Data Collection}

In the study beels farmers started Boro rice cultivation in December 2006. The land soaking, land preparation and transplantation of each site were done from $3^{\text {rd }}$ week of December to $2^{\text {nd }}$ week of January 2007. The growth of rice crop was seen from $2^{\text {nd }}$ or $3^{\text {rd }}$ week of January to $3^{\text {rd }}$ or $4^{\text {th }}$ week of April 2007. As a sample of 30 farms were taken at each site for monitoring production, and the yields were valued with prevailing market price. Irrigation and rainfall water were normally used for rice crop cultivation, but the rainfall water was found to be very negligible for Boro rice crop cultivation during dry season. So the amount of rainfall water and nonbeneficial water consumption (loss of water for irrigation system) in rice farms were not considered for measuring WP in this study.

The monitoring of WP by boro rice yield at dry season was divided into two parts, direct observation and interview of landowners of various boro rice farms for inputs and outputs of rice production and direct observation of irrigated water amount in rice fields.

Data collection was done separately for large farms, medium farms and small farms, and during four periods namely seedling, land preparation, weeding and harvesting periods. However, 11 visits were done for irrigation water amount monitoring at rice fields during land soaking, vegetation phage, production phage and ripening phage. Production of rice yield and irrigated water application per unit area of rice farms were estimated by interviewing the farm households as well as observing the amount of irrigation water application at the farm level. Per hectare average yield of boro rice crop was estimated by the total production boro rice yield divided by the total cultivable area in sample rice farms. If the depth of irrigation water per hectare is $1 \mathrm{~mm}$, it is then considered that $10^{3} \mathrm{~m}$ water has been used per hectare for irrigation purpose.

\section{Models and Estimations}

Water use efficiency (WUE), irrigation efficiency (IE), and water productivity (WP) has been defined according to use, field of research and stakeholder. Crop physiologists defined WUE as carbon assimilated and crop yield per unit of transpiration (Viets, 1962), and then later as the amount of produce (biomass or marketable yield) per unit of evapotranspiration (ET). Taking into account that photosynthesis (and thus dry matter yield) and transpiration are related through the diffusion process of $\mathrm{CO}_{2}$ and $\mathrm{H}_{2} \mathrm{O}$, the efficiency of crop water use has been defined as,

Water efficeincy $=\frac{\text { Dry metter growth rate }}{\text { Transpiration rate }}=\frac{\mathrm{Y}\left(\mathrm{kg}^{-1} \mathrm{~d}^{-1}\right)}{\mathrm{T}\left(\mathrm{mm} \mathrm{d}^{-1}\right)}$

Irrigation specialists have demonstrated the term WUE to describe how effectively water is delivered to crop sand to indicate the amount of water wasted. But this concept provides only a partial view because it does not indicate the benefits produced, nor does it specify that water lost by irrigation is often reused by other uses (Seckler et al. 2003). In daily irrigation practices, WP is a more applicable term in equation 1, as it assimilates the rate of dry matter yield and transpiration over time, i.e. denoted as $Y$ and $T$ respectively.

$\mathrm{WP}_{\mathrm{T}}=\frac{\mathrm{Y}\left(\mathrm{kg} \mathrm{ha}^{-1}\right)}{\mathrm{T}(\mathrm{mm})} \rightarrow \frac{\mathrm{Y}\left(\mathrm{kg} \mathrm{ha}^{-1}\right)}{\mathrm{T}\left(\mathrm{m}^{3} \mathrm{ha}^{-1}\right)} \rightarrow \mathrm{kg} \mathrm{m}^{-3}$

Where, $1 \mathrm{~mm}$ is equivalent with $10 \mathrm{~m}^{3} \mathrm{ha}^{-1}$. When applying irrigation at field scale, it is generally difficult to distinguish plant transpiration $T(\mathrm{~mm})$ from soil evaporation $E(\mathrm{~mm})$. Hence, instead of WPт, WP used (Molden, 1997, Molden et al., 2001; Droogers \& Bastiaanssen, 2002, Kijne et al., 2003): 
$\mathrm{WP}_{\mathrm{ET}}=\frac{\mathrm{Y}\left(\mathrm{kg} \mathrm{ha}^{-1}\right)}{\mathrm{ET}\left(\mathrm{m}^{3} \mathrm{ha}^{-1}\right)} \rightarrow \mathrm{kg} \mathrm{m}^{-3}$

Where ET is the evapotranspiration of 'crop + soil'. Total dry matter yield $Y$ may also be transformed into marketable yield, i.e. $Y_{M}$. If the amount of irrigation and precipitation water is considered as 'water use of the crop' then WPI+P may be used,

$\mathrm{WP}_{\mathrm{I}+\mathrm{P}}=\frac{\mathrm{Y}\left(\mathrm{kg} \mathrm{ha}^{-1}\right)}{[\mathrm{I}+\mathrm{P}]\left(\mathrm{m}^{3} \mathrm{ha}^{-1}\right)} \rightarrow \mathrm{kg} \mathrm{m}^{-3}$

Where I stands for amount of seasonal irrigation and $\mathrm{P}$ for the seasonal precipitation. Where ER (effective rainfall) is very negligible resulting in very low precipitation like arid regions or for dry season crop, WP I+P maybe converted to WPI (Vazifedoust et al., 2008)

$\mathrm{WP}_{\mathrm{I}}=\frac{\mathrm{Y}\left(\mathrm{kg} \mathrm{ha}^{-1}\right)}{\mathrm{I}\left(\mathrm{m}^{3} \mathrm{ha}^{-1}\right)} \rightarrow \mathrm{kg} \mathrm{m}^{-3}$

At the field scale classical WP indicator is crop output and total water supplied (irrigation and effective precipitation) to the field as because it is more appropriate and easy to interpret by management (Senzanje et al., 2005). As the farmer is mainly interested in the economic yield of the crop, WP may be expressed in terms of money as,

$\mathrm{WP}_{\$}=\frac{\left(\$ \mathrm{~kg}^{-1}\right)\left(\mathrm{kg} \mathrm{ha}^{-1}\right)}{\mathrm{ET}\left(\mathrm{m}^{3} \mathrm{ha}^{-1}\right)} \rightarrow \$ \mathrm{~m}^{-3}$

So WP measurement is straight forward in crop per drop analysis, which analyzes output (benefit quantity or value of product), over quantity of input (volume of depleted water). So in dry season, productivity from rice cultivation is expressed by rice yield. The equation 7 measures the WP of crops in physical terms as,

$\mathrm{WP}_{\mathrm{y}}=\frac{Q_{v}}{W C}$

Where,

$\mathrm{WP}_{\mathrm{y}} \quad=$ water productivity in terms of crops yield

Qy $\quad=$ yield of crop as physical units

WC = consumption of depleted water, expressed in cubic meters

That is, physical productivity is the quantity (Qy) of product per unit quantity of depleted water. The equation 8 measures the WP in terms of value as:

$W P_{y}=\frac{Q_{v}}{W C}$

Where,

$\mathrm{WPy}_{\mathrm{Q}} \quad=$ water productivity in monetary terms of crop

$Q_{V} \quad=$ gross/ net value of yield output in monetary terms

WC = consumption of depleted water, expressed in cubic meters

Again, it is evident that equation 8 is the more suitable measure in case of multi-product outputs. The value of output, $Q_{v}$, is the summation of values of different products resulting from application of unit amount of water.

The WP of rice crop in physical terms as,

$\mathrm{WP}_{\mathrm{y}}\left(\mathrm{Kg} \mathrm{m}^{-3}\right)=\frac{Q_{\mathrm{y}}(K g)}{W C\left(m^{3}\right)}$

$$
\mathrm{WC}\left(\mathrm{m}^{3}\right)=\mathrm{BWC}+\mathrm{NBWC}
$$

Where, 
$W P_{y} \quad=$ water productivity in physical units in terms of rice yield
$Q_{y} \quad=$ yield of rice crop, usually expressed in $\mathrm{Kg}$
$W C \quad=$ consumption of depleted water, expressed in cubic meters
BWC $\quad=$ beneficial water consumption in cubic meter
NBWC= Non-beneficial water consumption in cubic meter

The WP of rice crop in terms of value:

$\mathrm{WP}_{\mathrm{y}}\left(\mathrm{TK} \mathrm{m}^{-3}\right)=\frac{\mathrm{Q}_{\mathrm{v} 1}(\mathrm{TK})+\mathrm{Q}_{\mathrm{v} 2}(T K)}{\mathrm{WC}\left(\mathrm{m}^{3}\right)}$

Where,

$W P_{y} \quad=$ water productivity in terms of monetary valued

$Q_{v 1} \quad=$ value of net return by rice yield

$Q_{v 2} \quad=$ value of net return of by product

WC = consumption or depleted water

That is, WP is the value of product per unit quantity of depleted water. The same equation is also applicable for measuring WP of by product of crop. It is evident that equation 11 is the more suitable measure in case of multi-product outputs. The value of output, $Q_{v}$, is the summation of values of different products resulting from application of water.

This study used the WP by boro rice crop at farm level which was estimated by output of rice yield and it was by product with per cubic meter of irrigation water based on equation 9 to 11 .

\section{Assessment of Water Productivity Measurement of Cost of Production}

For producing boro rice per hectare average costs were calculated from sampled farms of boro rice in beel Mail and beel Chandpur. Per hectare full costs were calculated TK 31168.74 and TK 33237.94 for beel Mail and beel Chandpur, respectively by adding up all sorts of costs involved in producing rice crop. Whereas, per hectare cash variables costs for boro rice were estimated TK 24313.14 and TK 25667.59 which comprised $78 \%$ and $77.22 \%$ of total costs for beel Mail and beel Chandpur, respectively (Table 1). Irrigation water cost was found to be the most important cost as $24 \%$ and $22 \%$ for beel Mail and beel Chandpur, respectively.

In the winter season, boro rice crop is dependent on irrigation because of minimum or negligible rainfall. Without assured irrigation, the production cannot be expected high for this crop. Irrigation cost (calculated based on land size that is 33 decimal land= TK 1000 per season) found to be most important cost for boro rice production ranging from $22-24 \%$ of total production cost. The costs of irrigation water depend on number of irrigation required for crop cultivation. Among the sample crop farms, per hectare average costs of irrigation were TK 7488.88 in beel Mail and TK 7456.04 in beel Chandpur (Table 1).

Table 1. Economic analysis of per hectare boro rice production in seasonal beels.

\begin{tabular}{lcccc}
\hline \multirow{2}{*}{ Items } & \multicolumn{2}{c}{ Mail Beel } & \multicolumn{2}{c}{ Chandpur Beel } \\
\cline { 2 - 5 } & Value (TK) & $\%$ total cost & Value (TK) & \% total cost \\
\hline Cash expenses & 24313.14 & 78.00 & 25667.59 & 77.22 \\
Hire Labour cost & 6652.84 & 21.34 & 7228.35 & 21.75 \\
Fertilizers & 5561.00 & 17.84 & 5514.04 & 16.59 \\
\multicolumn{1}{c}{ DAP } & 2705.00 & - & 2579.70 & -
\end{tabular}




\begin{tabular}{lcccc}
\multicolumn{1}{c}{ Urea } & 1737.00 & - & 1507.24 & - \\
$\quad$ MP & 1119.00 & - & 1354.90 & - \\
Cow dung & 0 & - & 72.20 & - \\
Cost of seeds & 1562.93 & 5.01 & 1551.84 & 9.67 \\
Tractor use & 2246.75 & 7.21 & 3059.06 & 2.58 \\
Pesticides & 800.83 & 2.57 & 858.27 & 22.43 \\
Water cost & 7488.80 & 24.03 & 7456.04 & 22.78 \\
Non cash expenses & 6855.60 & 22.00 & 7570.34 & 16.92 \\
Lease values of land & 5625.03 & 18.05 & 5624.41 & 4.41 \\
Family labour & 774.55 & 2.49 & 1464.57 & 1.45 \\
Interest on operating capital & 456.02 & 1.46 & 481.36 & 100 \\
Full cost (TK) & 31168.74 & 100 & 33237.94 & \\
\hline
\end{tabular}

Source: Field survey data

Human labour cost is one of the most important variables input in the production process. Labour cost was found to be second most important production cost of boro rice cultivation. Both hired and family supplied labours were used for seedling, land preparation, plantation, fertilizers and pesticide uses, weeding and harvesting, threshing and carrying and drying and storage for production of boro rice crop (Table 1). To determine total labour cost unpaid family labour cost was taken into account. Table 2 shows the operationwise distribution of family and hired labour for per hectare crop production. For dry seasons per hectare crop production total hired labour cost was TK $6652.84(21.34 \%$ of total cost) and family labour cost was TK $774.55(2.49 \%$ of total cost) in beel Mail. In beel Chandpur for per hectare crop production total hired labour cost was TK 7228.35 (21.75\% of total cost) and family labour cost was TK 1464.57 (4.41\% of total cost).

Table 2. Operation wise distribution of human labour costs for boro rice production.

\begin{tabular}{lcccccccc}
\hline & \multicolumn{4}{c}{ Mail beel } & \multicolumn{5}{c}{ Chandpur Beel } \\
\cline { 2 - 10 } \multicolumn{1}{c}{ Operations } & \multicolumn{2}{c}{ Family labour } & \multicolumn{2}{c}{ Hire labour } & \multicolumn{2}{c}{ Family labour } & \multicolumn{2}{c}{ Hire labour } \\
\cline { 2 - 9 } & TK & $\%$ & TK & $\%$ & TK & $\%$ & TK & $\%$ \\
\hline Land preparation & 336 & 43.35 & 807 & 12.13 & 603 & 41.16 & 1478 & 20.45 \\
Transplanting & 78 & 10.06 & 1301 & 19.56 & 138 & 9.42 & 1390 & 19.23 \\
Weeding & 62 & 8 & 2168 & 32.59 & 115 & 7.85 & 2107 & 29.15 \\
Fertilizer used & 118 & 15.23 & 0 & 0 & 242 & 16.52 & 0 & 0 \\
Insecticide used & 56 & 7.23 & 0 & 0 & 89 & 6.08 & 0 & 0 \\
Harvesting, threshing and carrying & 58 & 7.48 & 1774 & 26.66 & 172 & 11.74 & 1738 & 24.05 \\
Drying and storage & 67 & 8.65 & 523 & 7.86 & 106 & 7.24 & 420 & 5.81 \\
Others & 0 & 0 & 80 & 1.20 & 0 & 0 & 95 & 1.31 \\
Total & 775 & 100 & 6653 & 100 & 1465 & 100 & 7228 & 100 \\
\hline
\end{tabular}

Source: Field survey data

Among the raw materials, fertilizer is another important cost item for boro rice crop cultivation. In the study area farmers used DAP, urea, TSP, potash (K) and cow-dung as fertilizer (organic and nonorganic). Table 1 shows per hectare average costs of fertilizer usage at boro rice crop farms. Among the sample crop farms average per hectare fertilizer costs were TK 5561 and TK 5514.04 which were $22 \%$ and $20 \%$ of total production cost for beel Mail and beel Chandpur, respectively. Costs of seed depend on variety or number of plants planted in the rice field by the farmers. In the sample crop farms, per hectare average cost of seeds were TK 1562.93 and TK 1551.84 which occupied $5.01 \%$ and $4.67 \%$ of total production cost for beel Mail and beel Chandpur, respectively (Table 1).Farmers used tractor for preparation of land for boro rice crop cultivation. This cost depends on work hour of tractor use for land preparation. Among the farms, per hectare 
average costs of tractor use were TK 2246.75 and TK 3059.06 which shared $7.21 \%$ and $9.2 \%$ of total costs of boro production for beel Mail and beel Chandpur respectively (Table 1).

Pesticides were used by the farmers during weeding period. Among the sample farms per hectare average costs of pesticide for boro rice crop were TK 800.83 and TK 858.27 which shared $2.57 \%$ and $2.58 \%$ of total production costs for beel Mail and beel Chandpur, respectively (Table 1).

The amount of money needed to meet the expenses of hired or purchased inputs such as, human labour, seeds, fertilizers, tractor use, pesticides and leveling etc. for boro rice cultivation were treated as operating capital. Interest on operating capital (IOC) was charged @ 10\% annually and was estimated for the period which the operating capital was used. IOC was estimated by using the following formula (Miah, 1987).

$$
\text { IOC }=\frac{\text { Operating capital } \times \text { Rate of interest } \times \text { Time consideration }}{2}
$$

IOC for boro rice production were estimated at TK 456.02 and TK 481.36 ha $^{-1}$ and it is constituted $1.46 \%$ and $1.45 \%$ of the total cost for beel Mail and beel Chandpur respectively (Table 1).

The value of land has been estimated according to average lease value (local price) of seasonal floodplain land of the farmers. Land is usually charged for 1 season or four and half months. During study period, per hectare boro rice land was charged TK 5625.03 and 5624.41 for 4.5 months that shared $18.05 \%$ and $16.92 \%$ of all cost in beel Mail and beel Chandpur respectively (Table 1). Cost of land (rent) was considered as opportunity cost as some of the sample farms were privately owned and did not require land value.

\section{Measurement of Returns of boro Production}

Per hectare average yields of boro rice were $4992.95 \pm 157.95 \mathrm{~kg}$ and $4783.20 \pm 117.15 \mathrm{~kg}$ in beel Mail and beel Chandpur, respectively. Average per hectare gross returns from sample boro rice farms were calculated TK 59873.31 \pm 1844.82 and TK $57642.10 \pm 1421.09$ for bee/ Mail and beel Chandpur respectively by value of rice yields and its by-products. The price rates were measured according to prevailing market price (Table 3 and Figure 2).

Table 3. Per hectare production of boro rice in seasonal rice field.

\begin{tabular}{lcccc}
\hline \multirow{2}{*}{ Particulars } & \multicolumn{2}{c}{ Beel Mail } & \multicolumn{2}{c}{ Beel Chandpur } \\
\cline { 2 - 5 } & Production & SD & Production & SD \\
\hline Average gross returns (TK) & 59873.31 & 1844.82 & 57642.10 & 1421.09 \\
$\quad$ Rice yield by value (TK) & 54922.41 & 1736.92 & 52615.20 & 1287.64 \\
$\quad$ By product of rice (TK) & 4950.90 & 118.77 & 5026.90 & 284.11 \\
Gross average cash cost (TK) & 24313.14 & 1687.50 & 25667.59 & 1061.4 \\
Gross average full cost (TK) & 31168.74 & 1611.52 & 33237.94 & 1931.99 \\
Net returns basis on cash cost (TK) & 35560.17 & 2317.93 & 31974.54 & 790.99 \\
Net returns basis on full cost (TK) & 28704.56 & 1144.68 & 24404.19 & 1115.67 \\
\hline
\end{tabular}

Source: Field survey data

\section{Measurement of Net Benefits of boro Production}

The per hectare returns over cash variables cost that is net profit of rice crop at beel Mail and beel Chandpur were TK $35560.17 \pm 2317.93$ and TK $31974.54 \pm 790.99$, respectively. Whereas it was TK $28704.56 \pm 1144.68$ and TK $24404.19 \pm 1115.67$ for beel Mail and beel Chandpur respectively on the basis of full cost. The net return of rice crop was found higher in the beel Mail than beel Chandpur (Table 3 and Figure 2). 


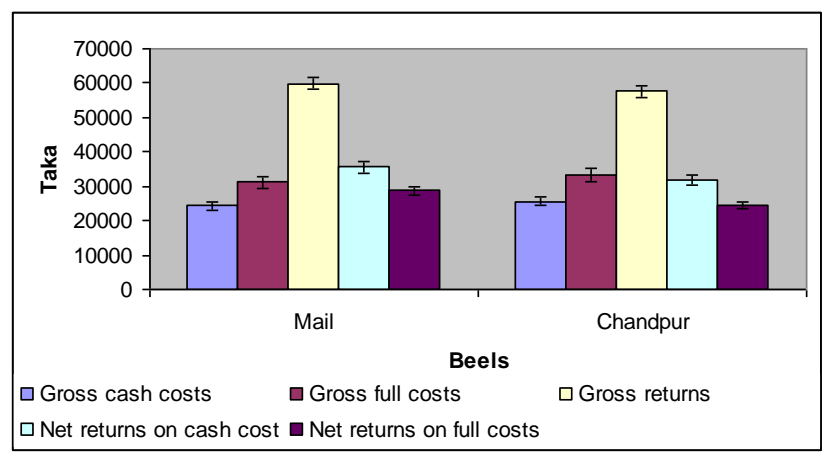

Fig. 2. Per hectare costs and returns of boro rice crop in sites of beel.

\section{Measurement of Usage of Water}

The amount of irrigation water required for crop cultivation was observed during land soaking, vegetation phage, production phage and ripening phage. If the depth of irrigation water per hectare is $1 \mathrm{~mm}$, it is then considered that $10 \mathrm{~m}^{3}$ of water has been used in per hectare area for irrigation purpose. The estimated irrigation water volume applied to the boro rice farms are summarized in Table 4.

Table 4. Average irrigated water $(\mathrm{mm})$ for boro rice cultivation at different stages.

\begin{tabular}{|c|c|c|c|c|}
\hline \multirow{2}{*}{$\begin{array}{l}\text { Growth } \\
\text { (week) }\end{array}$} & \multirow{2}{*}{$\begin{array}{l}\text { Cultivation period } \\
\text { (week) }\end{array}$} & \multicolumn{2}{|c|}{ Water depth $(\mathrm{mm})$} & \multirow{2}{*}{ Different phases of crop cultivatior } \\
\hline & & Mail beel & Chandpurbeel & \\
\hline & & 50 & 100 & $\begin{array}{l}\text { Soaking, land preparation, } \\
\text { transplanting }\end{array}$ \\
\hline 1 & Jan 3rd & 71.00 & 72 & \\
\hline 2 & Jan 4th & 92.33 & 88 & \\
\hline 3 & Feb 1st & 115.00 & 109 & Vegetatıon phase \\
\hline 4 & Feb 2nd & 131.00 & 128 & \\
\hline 5 & Feb 3rd & 132.33 & 133 & \\
\hline 6 & Feb 4th & 110.33 & 114 & \\
\hline 7 & Mar 1st & 63.67 & 61 & Reproductive phase \\
\hline 8 & Mar 2nd & 72.33 & 76 & \\
\hline 9 & Mar 3rd & 127.67 & 133.6 & \\
\hline 10 & Mar 4th & 107.33 & 109 & Ripening phase \\
\hline 11 & Apr 1st & 0 & 0 & \\
\hline 12 & Apr 2nd & 0 & 0 & No irrigation applied \\
\hline 13 & Apr 3rd & 0 & 0 & \\
\hline 14 & Apr 4th & 0 & 0 & Harvest \\
\hline & Total & 1073 & 1123.6 & \\
\hline
\end{tabular}

Source: Field survey data

After seven and eight weeks of transplanting, farmers commonly apply less water to encourage tillering of rice plants. At beel Mail, water depth was $50 \mathrm{~mm}$ during land socking and land preparation, and $1023 \mathrm{~mm}$ for crop growth. In beel Chandpur water depth was $100 \mathrm{~mm}$ during land socking and land preparation, and $1023.6 \mathrm{~mm}$ for crop growth (Table 4).

Measurement of Water Productivity 
After flood drawdown, rice crop cultivation on dry land of beels is mostly dependent on irrigation due to minimum or no rainfall during this period. The abstraction of water used at rice farms were directly related to deep tube-well (underground water) or both underground and surface water of floodplain beels.

Almost all of the cases the irrigated water was collected from Deep tube-well water (DTW). Amount of water consumption for rice crop was measured by millimeter $(\mathrm{mm})$ of irrigated water. Table 5 shows the average water consumption at per hectare area for boro crop cultivation. The volumes of water consumption at farm level of beel Mail and beel Chandpur were $10730.5 \mathrm{~m}^{3}$ ha-1 and $11236 \mathrm{~m}^{3}$ ha-1 respectively.

Table 6 shows the WP by irrigated boro rice in winter season (dry beel) at the rice farms of beel Mail and beel Chandpur. Physical WP value ranged from 0.41 to $0.50 \mathrm{Kg} \mathrm{m}^{-3}$ among the selected rice farms in two floodplain beels. The range of physical WP was $0.44-0.50 \mathrm{Kg} \mathrm{m}^{-3}$ (average $0.47 \pm 0.018 \mathrm{Kg} \mathrm{m}^{-3}$ ) at beel Mail, with an average yield of $4992.95 \pm 157.92 \mathrm{~kg}$ and WC ha-1 of $10730.5 \mathrm{~m}^{3}$ and at beel Chandpur range of physical WP was $0.41-0.47 \mathrm{Kg} \mathrm{m}^{-3}$ (average $0.43 \pm 0.014 \mathrm{Kg} \mathrm{m}^{-3}$ ) with an average yield of $4783.20 \pm 117.15 \mathrm{~kg}$ and WC ha-1 of $11236 \mathrm{~m}^{3}$.

However, in bell Mail, WP values in monetary term were estimated TK $5.65 \pm 0.212 \mathrm{~m}^{-3}$, TK $3.42 \pm 0.243 \mathrm{~m}^{-3}$ and TK $2.64 \pm 0.109 \mathrm{~m}^{-3}$ for rice crop and its by-product based on gross returns, net return based on cash costs and net return based on full costs respectively. WP values in beel Chandpur were TK $5.19 \pm 0.163 \mathrm{~m}^{-3}$, TK $2.87 \pm 0.085 \mathrm{~m}^{-3}$ and TK $2.14 \pm 0.098 \mathrm{~m}^{-3}$ for rice crop and its byproduct based on gross returns, net return based on cash costs and net return based on full costs respectively (Table 6).

Table 5. Per hectare water consumption of boro rice.

\begin{tabular}{lccc}
\hline \multirow{2}{*}{ Name of beels } & \multicolumn{3}{c}{ Average water consumption per hectare } \\
\cline { 2 - 4 } & Water depth $(\mathrm{mm})$ & SD & Volume of water $\left(\mathrm{m}^{3}\right)$ \\
\hline Beel Mail & 1073.05 & 166.58 & 10730.5 \\
Beel Chandpur & 1123.6 & 81.07 & 11236 \\
\hline
\end{tabular}

Source: Field survey data

Table 6. Water productivity by boro rice crop in two beels.

\begin{tabular}{lcccc}
\hline \multirow{2}{*}{ Water productivity } & \multicolumn{2}{c}{ Beel Mail } & \multicolumn{2}{c}{ Beel Chandpur } \\
& WP $\left(\mathrm{m}^{-3}\right)$ & SD & WP $\left(\mathrm{m}^{-3}\right)$ & SD \\
\hline WP range by rice yield $(\mathrm{Kg})$ & $0.44-0.50$ & - & $0.41-0.47$ & - \\
WP by rice yield (Kg) & 0.47 & 0.018 & 0.43 & 0.014 \\
WP by gross return (TK) & 5.65 & 0.212 & 5.19 & 0.163 \\
WP by net return based on cash cost(TK) & 3.42 & 0.243 & 2.87 & 0.085 \\
WP by net return based on full cost (TK) & 2.64 & 0.109 & 2.14 & 0.098 \\
\hline
\end{tabular}

Source: Field survey data

\section{Correlation among the Variables}

Pearson correlation analysis shows that WP by boro rice yield in beel Mail has a positive significant correlation with rice yield $(r=0.916, p<0.01)$ and negative significant correlation with water volume $(r=-0.583$, p<0.01) (Table 7).

Table 7. Correlation and significant test of water productivity with water volume and returns in Beel Mail. 


\begin{tabular}{|c|c|c|c|c|c|c|c|c|}
\hline Particulars & WV & RY & GR & NRBCC & NRBFC & WPBRY & WPBGR & WPBNCC \\
\hline $\mathrm{RY}$ & -0.242 & & & & & & & \\
\hline GR & -0.252 & $1.00^{\star *}$ & & & & & & \\
\hline NRBFC & $-0.401^{*}$ & $0.697^{\star *}$ & $0.693^{* *}$ & & & & & \\
\hline NRBFC & 0.107 & $0.509^{* *}$ & $0.501^{* *}$ & 0.202 & & & & \\
\hline WPBRY & $-0.583^{* *}$ & $0.916^{* *}$ & $0.919^{* *}$ & $0.743^{* *}$ & 0.352 & & & \\
\hline WPBGR & $-0.618^{* *}$ & $0.912^{* *}$ & $0.917^{* *}$ & $0.732^{* *}$ & $0.362^{*}$ & $0.989^{* *}$ & & \\
\hline WPBNCC & $-0.576^{* *}$ & $0.671^{* *}$ & $0.670^{* *}$ & $0.980^{* *}$ & 0.156 & $0.788^{* *}$ & $0.785^{\star *}$ & \\
\hline WPBNFC & -0.273 & $0.583^{\star *}$ & $0.579^{\star *}$ & 0.340 & $0.927^{\star *}$ & $0.559^{* *}$ & $0.582^{\star *}$ & $0.362^{*}$ \\
\hline
\end{tabular}

Moreover, at beel Chandpur WP has positive significant correlation with rice yield $(r=0.972, p<0.001)$, whereas negative significant correlation with volume of irrigated water $(r=-0.933, p<0.001)$ (Table 8).

Again WP by boro rice of beel Mail has a positive significant correlation with gross return $(r=0.917, p<0.01)$ and net return based on cash cost $(r=0.980, p<0.01)$. However, water volume shows negative significant correlation with gross return $(r=-0.576, p<0.01)$ and net return based on cash cost $(r=-0.576, p<0.01)($ Table 7). Again at beel Chandpur, WP has a positive significant correlation with gross return $(r=0.996, p<0.01)$ and net return based on cash cost $(r=0.950, p<0.01)$. However, water volume shows negative significant correlation with gross return $(r=-0.964, p<0.01)$ and net return based on cash cost $(r=-0.719, p<0.01)($ Table 8). Here the sign of correlation of " $r$ " is positive means return will increase with increase of inputs and vice versa.

Table 8. Correlation and significant test of water productivity with water volume and returns in Beel Chandpur.

\begin{tabular}{|c|c|c|c|c|c|c|c|c|}
\hline Particulars & WV & RY & GR & NRBCC & NRBFC & WPBRY & WPBGR & WPBNCC \\
\hline RY & $-0.917^{* *}$ & & & & & & & \\
\hline GR & $-0.937^{\star \star}$ & $0.983^{\star *}$ & & & & & & \\
\hline NRBFC & $-0.548^{* \star}$ & $0.638^{* *}$ & $0.675^{\star \star}$ & & & & & \\
\hline NRBFC & 0.188 & -0.165 & -0.148 & 0.150 & & & & \\
\hline WPBRY & $-0.933^{* *}$ & $0.972^{\star \star}$ & $0.965^{\star *}$ & $0.653^{* *}$ & -0.182 & & & \\
\hline WPBGR & $-0.964^{\star *}$ & $0.977^{\star \star}$ & $0.996^{\star *}$ & $0.655^{\star *}$ & -0.158 & $0.969^{\star *}$ & & \\
\hline WPBNCC & $-0.719^{* *}$ & $0.771^{\star *}$ & $0.805^{* *}$ & $0.975^{* *}$ & 0.073 & $0.787^{* *}$ & $0.796^{* *}$ & \\
\hline WPBNFC & 0.041 & -0.035 & -0.014 & 0.224 & $0.989^{* *}$ & -0.049 & -0.019 & 0.174 \\
\hline
\end{tabular}

${ }^{* *}$ Correlation is significant at the 0.01 level (2-tailed).

\section{Discussions}

This study found gross WP of rice yield at $0.47 \pm 0.018 \mathrm{~kg} \mathrm{~m}^{-3}$ in beel Mail and $0.43 \pm 0.014 \mathrm{~kg} \mathrm{~m}^{-3}$ in beel Chandpur during dry season, which is also similar to the findings of Cai, Ximing and Rosegrant (2003). They showed that world WP of rice yield in 1995 was 0.15 to $0.60 \mathrm{Kg} \mathrm{m}^{-3}$ which will increase from 1995 to 2025. The findings of this study are a little higher than the WP value in Pakistan but lower than the findings in Philippines and China. The WP values for gross inflow of irrigation were $0.27 \mathrm{~kg} \mathrm{~m}^{-3}$ ranging from $0.20 \mathrm{~kg} \mathrm{~m}^{-3}$ to $0.31 \mathrm{~kg} \mathrm{~m}^{-3}$ in Punjab, Pakistan. The irrigation WP of traditional rice cultivation in Tuanlin China was 1.95 
$\mathrm{kg} \mathrm{m}^{-3}$ (Dong et al. 2001) and in Philippines for wet seeded rice was 1.4 to $1.6 \mathrm{~kg} \mathrm{~m}^{-3}$ (Toung and Bouman 2002). This variation may be due to variations of rice crop cultivated, land, and usage of fertilizer, environment and cultivating technology.

Again in dry season WP from per cubic meter irrigation water in monetary term of beel Mail were TK $5.65 \pm 0.212$, TK $3.42 \pm 0.243$ and TK $2.64 \pm 0.109$ based on gross return, net return considering cash costs and net return considering full costs. However, in beel Chandpur these values were TK $5.19 \pm 0.163 \mathrm{~m}^{-3}$, TK $2.87 \pm 0.085 \mathrm{~m}^{-3}$ and TK $2.14 \pm 0.098 \mathrm{~m}^{-3}$. It was also evident from the study that higher WP was obtained in beel Mail area than beel Chandpur area in dry season due to higher gross yield of boro rice against less amount of irrigation water used. The usage of average irrigation water in the boro rice farms were estimated $10730.05 \pm 166.58 \mathrm{~m}^{-3}$ and $11236 \pm 81.07 \mathrm{~m}^{-3}$ with an average production of yield $4992.95 \pm 157.92 \mathrm{~kg}$ and $4783.20 \pm 117.15 \mathrm{~kg}$ in beel Mail and beel Chandpur, respectively. Statistical correlation indicates that $1 \%$ increase of rice yield of boro rice crop, keeping irrigation water constant at farm levels in beel Mail will increase $0.916 \%$ of WP, whereas $1 \%$ volume of irrigation water increase, keeping rice yield of rice crop constant, would result in decrease of WP by $0.583 \%$. Again at beel Chandpur, $1 \%$ increase of rice yield of boro rice crop, keeping irrigation water constant, will increase $0.972 \%$ of WP, and $1 \%$ volume of irrigation water increase, keeping rice yield of rice production constant, would result in decrease WP by $0.933 \%$.

WP of boro rice yield per cubic meter of water use was $4.65 \%$ higher in beel Mail than beel Chandpur. Production cost considering material input costs were also found less in beel Mail specially tractor and labeling cost during land preparation resulting in higher net WP. Per hectare land preparation cost was TK 4769 which shared less than $40 \%$ of the production cost in beel Mail whereas the cost was TK 6668 which shared above $60 \%$ of the production cost for beel Chandpur. Per hectare cost for land preparation was more than $28 \%$ higher in beel Chandpur compared to bee/ Mail.

\section{Conclusions}

It was found that WP values were higher in beel Mail than the beel Chandpur due to intervention of community based fish culture. In dry season land preparation cost was less in beel Mail area because water was reserved for fish culture till boro rice cultivation so that land was swallow and no weed.

\section{Acknowledgements}

The authors would like to acknowledge the financial support for this research from the World Fish Center (Community Based Fish Culture in Irrigation System and Seasonal Floodplain Project (CP35) funded by CGIAR Challenge Program Water \& Food, April 2005 -31 Dec 2010) and Malaysian Commonwealth Scholarship (MCS), Ministry of Higher Education, Malaysia (Ref. KPT (BS) 035/11/002, 15.2.200631.5.2009).

\section{References}

Alam MS, Hossain MS. (2007). "Beel". Banglapedia. Asiatic Society of Bangladesh. http://banglapedia.search.com.bd/HT/B_0382.htm. (23rd nov. 2007)

Bastiaanssen WGM, Van Dam JC, Droogers P. (2003). Introduction. In Dam, J.C. van, and R.S. Malik (Eds.), 2003. Water productivity of irrigated crops in Sirsa district, India. Integration of remote sensing, crop and soil models and geographical information systems. WATPRO final report, including CD-ROM. 6, 11-19.

Bessembinder JJE, Leffelaar PA, Dhindwal AS, Ponsioen TC. (2005). Which crop and which drop, and the scope for improvement of water productivity. Agric. Water Manage. 73 (2), 113-130.

Cai, X. and Rosegrant, M. (2003). World water productivity: Current situation and future options. In: Kijne, J.W., Barker, R. and Molden, D. (Eds.) Water Productivity in Agriculture: Limits and Opportunities for Improvement. CABI, Wallingford, 163-178.

Dong B, Loeve R, Li YH, Chen CD, Molden D. (2001). Water productivity in Zhanghe irrigation system: Issues of scale. Proceedings of an international workshop on water saving irrigation for rice. Wuhan, China. 
Droogers P. Bastiaanssen WGM. (2002). Irrigation performance using hydrological and remote sensing modelling. J. of Irrigation and Drainage Engineering 128, 11-18.

Dugan PJ, Dey MM, Sugunan VV. (2006). Fisheries and Water productivity in tropical river basins:enhancing food security and livelihoods by managing water for fish. Agricultural Water Productivity. 80, 262-275.

FAO. (2001). The economics of conservation agriculture. Rome, Italy: FAO, Land and water development division, Food and Agriculture organization of the United Nations.

FAO. (2003). Raising water productivity. Issues in world agriculture 2001-2004, Spotlight 2001-2004. http://www.fao.org/AG/magazine/0303sp2.htm, (4th July 2007) pp-?

Guerra LC, Bhuiyan SI, Tuong TP, Barker R. (1998). Producing more rice with less water from irrigated systems. SWIM Paper 5. Sri Lanka, Colombo: International Water Management Institute.

Hofer T, Messerli B. (1997). Floods in Bangladesh; Process Understanding and Development Strategies. Institute of Geography, Univ. of Beren, Switzerland. http://www.blackwell-synergy.com/doi/pdf/10.1046/j.13652400.2003.00339.x. (5th May 2007).

IFAD, WorldFish Center (2002). Increasing and Sustaining the Productivity of Fish and Rice in the Flood-prone Ecosystems in South and Southeast Asia.

Kijne J, Barker R, Molden D. (Eds.) (2003). Water productivity in agriculture: limits and opportunities for improvement. Comprehensive assessment of Water Management in Agriculture, Series No. 1, CABI press, Wallingford, UK, 352 $\mathrm{pp}$.

Merrett S. (1997). Introduction to the economics of water resources: An international perspective. London: University College London Press.

Miah MTH.(1987).Appraisal of deep shallow tube well irrigation project in the Tangail District in Bangladesh, MSC Dissertation. University of New England, Armidale, Australia.

Molden D, Sakthivadive R. (1999). Water Accounting to Assess Use and Productivity of Water. International Journal of Water Resources Development, 15, 55-71.

Molden D. (1997). Accounting for water use and productivity. SWIM Paper 1. Colombo, Sri Lanka: International Irrigation Management Institute.

Molden D, Murray-Rust H, Sakthivadivel R,Makin I. (2001). A water productivity framework for understanding and action. Workshop on Water productivity. Wadduwa, Sri Lanka, November 12 and 13, 2001.

Molden D, Sakthivadivel R, Perry CJ, de Fraiture, C. Kloezen, WH. (1998). Indicators for comparing performance of irrigated agricultural systems. Research report 20.Colombo, Srilanka: International Water Management Institute.

MPO.(1986). National Water Plan. Sector Analysis. Master Plan Organization (MPO) Technical Report No. 1, Ministry of Water Resources, Dhaka.

Nishat A. (1990). Background Paper on Water Resources and Flood Control. Department of Water Resources Engineering, Bangladesh University of Engineering and Technology, Dhaka.

Pimentel D, Berger B, Filiberto D, Newton M, Wolfe B, Karabinakis E, Clark, S, Poon, E, Abbett, E, Nandagopal S. (2004). Water resources: agricultural and environmental issues. Bioscience. 54 (10), 909-918.

Powell W, Gabe. (2009). Identifying Land Use/Land Cover (LULC) Using National Agriculture Imagery Program (NAIP) Data as a Hydrologic Model Input for Local Flood Plain Management. Applied Research Project, Texas State University. http://ecommons.txstate.edu/arp/296, (6th May 2007).

Rahman AKA. (1989). Freshwater of Bangladesh. Zoological Society of Bangladesh, Dhaka, 364-366 pp.

Rijsberman FR. (2006). Water scarcity: fact or fiction? Agricultural Water Management. 80, 5-22. 
Seckler D, Molden D,Sakthivadivel R. (2003). The concept of efficiency in water-resources management and policy. In: Kijne et al. eds. 2003. Water Productivity in Agriculture: Limits and Opportunities for Improvement. CABI Publishing, Wallingford, UK, 37-51.

Senzanje A, Chimunhu T, Zirebwa J. (2005). Assessment of water productivity trends for parastatal agricultural operations-case of Middle Sabi Estate, Zimbabwe. Physics and Chemistry of the Earth. 30, 767-771.

Sharma BR. (2006). Crop Water Requirements and Water Productivity: Concepts and Practices, presented on October 30, 2006; 1200-1300 hrs, in College of Agricultural Engineering, Punjab Agricultural University, Ludhiana.

Thompson PM, Sultana P, Islam MN, Kabir MM, HossainMM, Kabir MS. (1999). An assessment of co-management arrangements developed by the Community Based Fisheries Management Project in Bangladesh, Paper Presented at the International Workshop on Fisheries Co-management, 23-28 August 1999, Penang, MalaysiaToung and Bouman 2002.

Toung TP. Bouman BMA. (2002). Rice production in water scarce environments. In Water productivity in agriculture: limits and opportunities for improvement, Ed. J. W. Kijni. Wallingford,UK: CABI.

Tsai CF, Ali MY, Ahsan K, Alam SS. (1993). 'Household fish consumption in relation to fishing practices and fish production in flood plains of Bangladesh'. Indian Fisheries Journal. 40(3), 181-188.

Vazifedoust M, Van Dam JC, Feddes RA, Feizi M. (2008). Increasing water productivity of irrigated crops under limited water supply at field scale. Agricultural water management. 95, 89 - 102.

Viets Jr, FG. 1962. Fertilizers and the efficient use of water. Advances in Agronomy. 14, 223-264.

Welcomme RL. (1979). Fisheries Ecology of Floodplain Rivers. Longman, London.

Zwart SJ, Bastiaanssen, WGM. (2004). Review of measured crop water productivity values for irrigated wheat, rice, cotton and maize. Agricultural Water Management. 69(2), 115-133. 